Г.I.Чепурко,

доктор соиіологічних наук, завідувач відділу соиіальної експертизи Інституту соиіологї̈ НАН України,

\title{
В.М.Головатюк,
}

доктор економічних наук, провідний науковий співробітник Інституту досліджень науково технічного потенціалу та історії науки ім. Г.М.Доброва НАН України,

\author{
І.Д.Піддубний, \\ студент факультету \\ економічних наукНаУКМА
}

\section{СОЦІАЛЬНИЙ ПОТЕНЦІАЛ МОДЕРНІЗАЦІЇ УКРАЇНСЬКОЇ ЕКОНОМІКИ В КОНТЕКСТІ ЄВРОІНТЕГРАЦІЇ}

За сучасної глобальної спрямованості суспільного розвитку дедалі нагальнішою стає участь України в планетарній конкурентній боротьбі за своє майбутнє. У контексті європейської інтеграції особливістю цього процесу є вимога перманентних трансформацій у виробництві, активації креативності соціальних ресурсів, продукуванні науково обгрунтованих розробок, використанні новітніх технологій. Наразі такий перебіг реалій ініціює розвиток нової економіки. Вона може сформуватись лише за умов певної стратегії модернізації українського суспільства, а отже і його фундаменту-економіки.

Європейська інтеграція є стратегічним пріоритетом і шансом сучасної України для перманентної модернізації національної економіки. У цьому контексті доцільно виявити особливості нарощування потенціалу/ресурсу інноваційного економічного розвитку української економіки крізь призму активного використання іiі соціального потенціалу, завдяки модернізації.

Зарубіжні [1] та вітчизняні публікації [2] засвідчують, що важлива роль при цьому надається вирішенню проблеми нарощування і 
використання соціального потенціалу інноваційного економічного розвитку, дослідженню та осмисленню значення якого за сучасної глобалізації вельми актуально.

Отже, метою нашого дослідження є аналіз впливу соціального потенціалу на модернізацію економіки України в загальному контексті євроінтеграції.

Сучасні соціальні теорії розглядають модернізацію в трьох взаємопов'язаних вимірах: економічного розвитку, інституціональних змін (зокрема, демократизації політичної системи) і формування емансипаційних цінностей [3, 130-131].

Пріоритетним напрямом наявних досліджень $є$ макроекономічний та інституціональний аналіз, що демонструє світову тенденцію, згідно з якою для ефективного економічного розвитку необхідні інституціональні та соцієтальні зміни, перехід від соціального порядку обмеженого доступу до відкритого доступу світ-системного масштабу.

Стан економіки України (неконкурентоспроможна, стагнаційна, наздоганяюча) потребує невідкладних заходів, котрі дали б можливість виходу на траєкторію іiі відновлення, на засадах підвищення конкурентоспроможності, створення і реалізації моделі модернізаційного розвитку в європейському контексті. Долучення до цього цивілізаційного об’єднання є нагальною потребою, особливо для країн, що перебувають у точці біфуркації часу свого функціонування, позаяк це зумовлено перспективами їх входження в соціальний простір глобалізаційних змін.

Інтеграція до європейської цивілізації - це масштабне завдання сучасної України для суттєвого подолання технологічної відсталості, модернізації національної економіки, сприяння розвитку наукових знань, відкритості індивіда до інновацій. Тому важливо акцентувати увагу на ролі соціального потенціалу в радикальній трансформації / інноваційному розвитку української економіки [4].

Соціальний потенціал (потенційні «соціальні можливості», «social capability») інноваційного економічного розвитку, за концепцією М.Абрамовича та П.Девіда [5, 145], є однією з вагомих складових «потенціалу наздоганяючої конвергенції». Другою складовою цього феномена автори вважають «потенціал технологічної конгруентності» («technological congruence»). Наявність та синергетична взаємодія означених потенціалів й зумовлює інноваційний економічний розвиток наздоганяючої країни. У такому розумінні ці потенційні можливості пов'язуються 3 такими атрибутами й характеристиками 
людей та економічних структур, які ініціюються соціальними й політичними інституціями і впливають на реакцію людей щодо можливостей економічного зростання якості соціального життя.

Загалом умови, які регулюють можливості країни у модернізації продуктивності економіки, можна типізувати таким чином: 1) ті, що створюють потенціал країни, аби підвищувати свій рівень продуктивності, і 2) ті, що впливають на їх здатність реалізовувати цей потенціал.

Отже, дослідження М.Абрамовича та П.Девіда дає підстави вважати, що соціальний потенціал інноваційного/модернізаційного економічного розвитку, завдяки стабільній та обгрунтованій державній політиці у визначенні й практичній реалізації нарощування національної економіки, зумовлює іiї спроможність як на створення ефективного потенціалу країни для зростання своєї продуктивності, а відтак і конкурентоспроможності, так і реалізовувати такий потенціал. А це включає наступне: продуктивне освоєння нових технологій; залучення соціального капіталу, набуття досвіду і вмінь в організації й управлінні масштабними проектами, виробничими підприємствами та сервісними фірмами; конкурування на глобальному рівні тощо.

Така парадигма дає підстави вважати, що модернізація важлива як сукупність процесів, через які слаборозвинуті суспільства або суспільства, що розвиваються, намагаються скоротити чи подолати розрив, що віддаляє їх від розвинутих країн в економічному зростанні, конкурентоспроможності у глобальному просторі і якості життя населення $[6,25]$. Водночас, таке розуміння містить універсалістський потенціал, який реалізується в соцієтальному і культурному здобутках людства. У цьому плані відзначимо, що в процес модернізації нерозривно вбудовані соціокультурні виміри: емансипаційні ціннісні орієнтації, раціональна парадигма світосприйняття, індивідуальна відповідальність, критичне мислення, громадянська активність тощо. Універсальні модерні виміри завжди пов'язані з конкретно історичними умовами і втілюються через національний контекст. Це породжує специфічні конфігурації й може призводити до соціальних дисфункцій та конфліктів. Відповідно, виявлення таких деформацій, що склалися в Україні, $є$ актуальним дослідницьким завданням [7, 19].

У сьогоденному турбулентному світі для України потрібна інноваційна парадигма розвитку суспільства нового типу, яка започаткувала б реальну стратегію іiі інноваційної модернізації. Під інноваційною 
модернізацією розуміється продуктивне технологічне, господарськоекономічне, соціально - політичне й гуманітарне оновлення сучасного українського суспільства, яке повинно відбуватися на засадах випереджаючого, а не наздоганяючого розвитку. Базові завдання української модернізації - це створення сучасного суспільства, 3 відповідними соціальними інституціями, ефективної економіки та матеріально-соціальної інфраструктури для раціональної організації основних видів діяльності людини у всіх сферах суспільного життя. Головна мета модернізації у глобальному вимірі - забезпечення світової конкурентоспроможності України як держави та інтегрованого суспільства, що має мобілізаційну силу солідарної діяльності історичного суб'єкта.

Відзначимо, що доволі вагомими складовими соціального потенціалу модернізації економіки нашої країни є такі: соціальний капітал, соціально-економічне середовище (CEC), державна влада, науковий потенціал.

Соціальний капітал має ключове значення як природний інтегратор для розвитку соціуму, оскільки він безпосередньо впливає на характер суспільних відносин, забезпечуючи позитивні перетворення в соціально-економічній та суспільно-політичній сферах на рівні міжгрупової, корпоративної та інституціональної взаємодії. Він виступає як модус консолідованих дій у соціальних процесах, які суттєво впливають на модернізацію економіки.

Розглядаючи суспільство як accumulated history, слід звернути увагу на феномен капіталу. Виступаючи потенційною здатністю продукувати прибуток і відтворювати себе в існуючих чи розширених формах, він зберігає в собі тенденцію до стабільності. А дистрибуція різних типів капіталу створює іманентну структуру суспільства. Вона являє собою сукупність можливостей, умов і практик соціального характеру, що вписуються в саму реальність, і відповідно в успіх його функціонування, визнаючи пріоритетність економічного капіталу. Тобто результативне функціонування економіки пов'язане iз соціальним капіталом як суспільним ресурсом, інкорпорований стан якого передусім фіксується в понятті «довіра».

Довіра в економічних відносинах виконує низку важливих соціальних функцій, через які й відбувається уможливлення інноваційного розвитку економіки країни. Ці функції реалізуються через виникнення, завдяки довірі, широкій палітрі соціальних контактів, які сприяють появі та впровадженню інноваційних форм організації, 
поширенню й прийняттю нових компонентів матеріальної і духовної культури. Відтак, довіру в макроекономічних комунікаціях можна розглядати як одну зі складових соціального потенціалу інноваційної модернізації економіки країни.

Знаний американський дослідник Ф.Фукуяма підкреслює важливість соціокультурних, зокрема ціннісних чинників довіри: «Як правило, довіра виникає в тому випадку, якщо суспільство розділяє певний набір моральних цінностей і його члени внаслідок цього можуть покладатися на передбачувану і чесну поведінку один одного. В якомусь сенсі сам характер цих цінностей не так важливий як те, що вони є для людей загальними» [8, 257].

Модернізація української економіки на сьогодні дедалі більше залежить від якісно нового соціально-економічного середовища (CEC) як сукупності необхідних умов/ресурсів функціонування країни, що забезпечують сталість відтворення рівня якості життєдіяльності суспільства. За такої ситуації цілком правомірно спиратися на вирішення проблеми інноваційності СЕС з урахуванням інтересів інвестора, продуктивного агента і національної економіки. Саме узгодженість інтересів цієї тріади відкриває перспективу формування CEC, необхідного для реалізації стратегії випереджаючої модернізації економіки завдяки активізації інноваційних чинників, зокрема, формування привабливого інвестиційно-інноваційного клімату СЕС. Підкреслимо, що такий клімат виступає інтегральною характеристикою, яка базується на комплексі політичних, економічних i соціальних умов, забезпечуючи спроможність економічної системи продукувати свій розвиток, більш ефективно використовуючи інноваційний та соціальний капітал [9].

Якщо простежити динаміку індексу глобальної конкурентоспроможності (GCI) України впродовж 2009-2015 pр., де враховується період після всесвітньої економічної кризи, а також і те, що методологія визначення цього індексу розрахована на оцінки соціально-економічних середовищ країни у середньостроковій перспективі, можна виявити, що його бальна оцінка змінювалась у межах 3,95-4,14 бала 3 вищими їх значеннями, характерними для 2013-2015 pp. За цей період покращився на 6 пунктів і ранг України за індексом GCI (з 82 рангу до 76 рангу). Отже, доцільно вважати, що в межах концептуальних положень обрахунку індексу глобальної конкурентоспроможності Всесвітнього економічного форуму [10] простежується певною мірою тенденція щодо покращення інвестиційної приваб- 
ливості соціально-економічного середовища української економіки.

Загалом аналіз даних за 2011-2015 pp. засвідчує, що привабливість українського СЕС покращилась за більшістю оцінок фактор-складових означеного індексу як за рангом, так і за балами. Так, субіндекс «базові вимоги» покращився за рангом на 11 пунктів (3 98 до 87 пунктів), а за балами на 0,18 пунктів (від 4,18 до 4,36 пунктів); субіндекс «підсилювачі ефективності» зріс за рангом на 7 пунктів (з 74 до 67 пунктів) і за балами на 0,11 пунктів (від 4,00 до 4,11 пунктів) [11].

Щодо України можна зазначити, що соціальний потенціал модернізації економіки доволі слабко сприяє зменшенню ііі інноваційної периферійності. Про це свідчать, зокрема, результати експертного опитування (табл. 1,2), проведеного у 2013 р. Інститутом соціології НАН України з метою «пошуку нової парадигми трансформації і модернізації української економіки у XXI ст.» $[12,71]$, експертами в якому виступали також фахівці Інституту досліджень науковотехнічного потенціалу та історії науки ім. Г.М.Доброва НАН України.

Соціальний потенціал інноваційного розвитку національної економіки трактується дослідниками як «сукупна здатність різноманітних соціальних груп і суспільства загалом створювати, сприймати, впроваджувати і поширювати нововведення, що забезпечують економічний розвиток, а також організаційно-інституціональні можливості здійснення інноваційних практик соціальних суб'єктів економічної діяльності» $[12,68]$. На нашу думку, сукупний соціальний потенціал інноваційного розвитку економіки (IPE) базується на таких його субпотенціалах (компонентах): соціально-політичному, соціально-економічному, соціокультурному, науковому, освітньому та інституціональному.

Важлива методологічна особливість проведення цього дослідження полягала в тому, що експерти оцінювали і досягнутий рівень складових соціального потенціалу інноваційного розвитку української економіки, і їхню нормативну роль, яку вони повинні відігравати в забезпеченні продуктивного інноваційного поступу економіки. Таким чином, за результатами експертних оцінок є можливість порівнювати реальний стан соціального потенціалу інноваційного розвитку української економіки з експертно визначеним нормативно бажаним його рівнем (табл. 1, 2). 
Табличя 1

Показники соціально-політичного, соціальноекономічного та інституціонального субпотенціалів інноваційного розвитку економіки України, 2013, (бали ${ }^{\text {a }}$

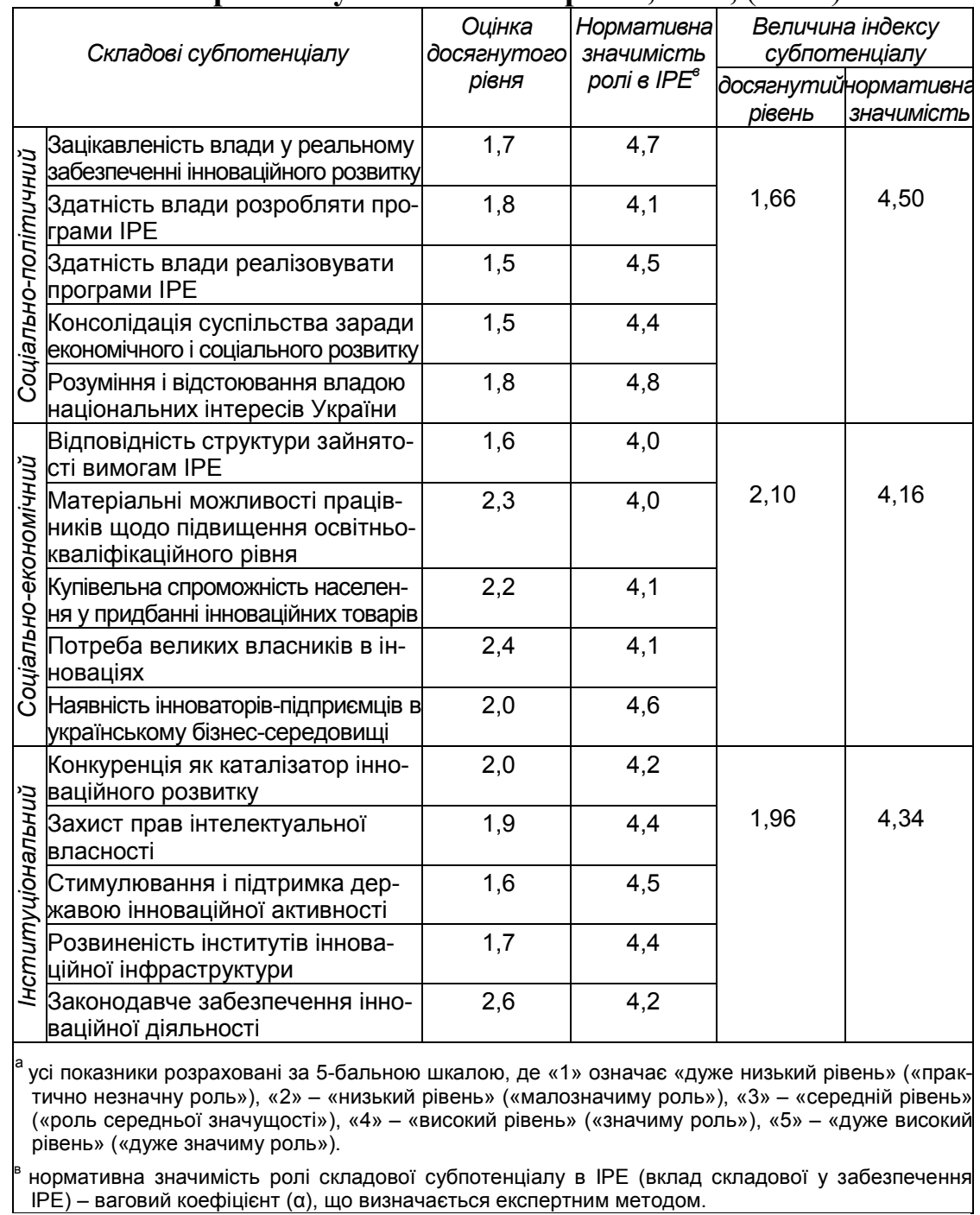

Джерело: [12, 73]. 
Табличя 2

Показники соціокультурного, наукового та освітнього субпотенціалів інноваційного розвитку економіки України, 2013, (бали $\left.{ }^{\mathrm{a}}\right)$

\begin{tabular}{|c|c|c|c|c|c|}
\hline & \multirow[t]{2}{*}{ Складові субпотениіалу } & \multirow{2}{*}{\begin{tabular}{|c|} 
Оиінка \\
досягнутого \\
рівня
\end{tabular}} & \multirow{2}{*}{$\mid \begin{array}{c}\text { Нормативна } \\
\text { значимість } \\
\text { ролі в IPE }\end{array}$} & \multicolumn{2}{|c|}{$\begin{array}{l}\text { Величина індексу } \\
\text { субпотениіалу }\end{array}$} \\
\hline & & & & $\begin{array}{c}\text { досягнутий } \\
\text { рівень }\end{array}$ & $\begin{array}{c}\text { нормативна } \\
\text { значимість } \\
\end{array}$ \\
\hline \multirow{5}{*}{ 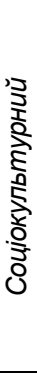 } & Інноваційна культура & 1,7 & 4,5 & \multirow{5}{*}{2,74} & \multirow{5}{*}{4,40} \\
\hline & $\begin{array}{l}\text { Творче ставлення людей до } \\
\text { роботи }\end{array}$ & 2,8 & 4,4 & & \\
\hline & $\begin{array}{l}\text { Прагнення людей до постійного } \\
\text { підвищення свого освітньо- } \\
\text { кваліфрікаційного рівня }\end{array}$ & 2,8 & 4,4 & & \\
\hline & $\begin{array}{l}\text { Цінність самореалізації у про- } \\
\text { фесійній діяльності } \\
\end{array}$ & 3,0 & 4,4 & & \\
\hline & $\begin{array}{l}\text { Цінність досягнення матеріаль- } \\
\text { ного благополуччя за допомо- } \\
\text { гою професійної діяльності }\end{array}$ & 3,4 & 4,3 & & \\
\hline \multirow{3}{*}{ 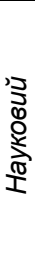 } & $\begin{array}{l}\text { Можливості науково-дослідних } \\
\text { колективів генерувати фунда- } \\
\text { ментальні ідеї }\end{array}$ & 3,2 & 4,5 & \multirow{3}{*}{2,90} & \multirow{3}{*}{4,37} \\
\hline & $\begin{array}{l}\text { Можливості науково-дослідних } \\
\text { колективів перетворювати нові } \\
\text { дееї в інновації }\end{array}$ & 2,3 & 4,4 & & \\
\hline & $\begin{array}{l}\text { Наявність вітчизняних наукових } \\
\text { шкіл }\end{array}$ & 3,2 & 4,2 & & \\
\hline \multirow{3}{*}{ : } & Рівень освіти населення & 3,5 & 4,2 & \multirow{3}{*}{2,87} & \multirow{3}{*}{4,37} \\
\hline & Якість системи освіти в країні & 2,7 & 4,5 & & \\
\hline & $\begin{array}{l}\text { Здатність працівників викорис- } \\
\text { товувати інноваційні знання та } \\
\text { технології }\end{array}$ & 2,4 & 4,4 & & \\
\hline
\end{tabular}

а усі показники розраховані за 5-бальною шкалою, де «1» означає «дуже низький рівень» («практично незначну роль»), «2» - «низький рівень» («малозначиму роль»), «3» - «середній рівень» («роль середньої значущості»), «4» - «високий рівень» («значиму роль»), «5» - «дуже високий рівень» («дуже значиму роль»).

в нормативна значимість ролі складової субпотенціалу в IPE (вклад складової у забезпечення IPE) - ваговий коефіцієнт $(\alpha)$, що визначається експертним методом.

Джерело: $[12,80]$.

Не вдаючись до ретельного аналізу результатів означеного експертного дослідження, можна виявити парадоксальну ситуацію, що склалася в соціально-економічному середовищі України. Найнижчу оцінку рівня розвитку отримали складові соціально-політичного субпотенціалу (1,66 бала), тобто фактори, що визначають компетентність та зацікавленість органів державної влади в ефективному інноваційному розвитку національної економіки. А мало б бути навпаки. Все-таки влада постійно декларує інноваційний розвиток 
української економіки і покликана реалізовувати цю політику. Тому, здавалося б, рівень іiі компетентності та зацікавленості в цьому питанні мали б бути достатньо високими, якщо не найвищими. Про що і засвідчили відповідні експертні оцінки - складові соціальнополітичного субпотенціалу щодо компетенції та зацікавленості органів державної влади в продуктивному інноваційному розвитку отримали найвищу нормативно-бажану значимість (4,50 бала).

Дійсність, утім, виявилася іншою. Так, реальний рівень «розуміння і відстоювання владою національних інтересів України» оцінено експертами в 1,8 бала, а нормативно-бажаний - в 4,8 бала; реальний рівень «зацікавленості влади у реальному забезпеченні інноваційного розвитку» оцінено в 1,7 бала, а нормативно-бажаний в 4,7 бала; реальний рівень «здатності влади реалізовувати програми IPE» оцінено в 1,5 бала, а нормативно-бажаний - в 4,5 бала; реальний рівень «здатності влади розробляти програми IPE» оцінено в 1,8 бала, а нормативно-бажаний - в 4,1 бала.

Цікаво, що за таких низьких оцінок компетентності та зацікавленості органів державної влади в ефективному інноваційному розвитку національної економіки довіра до науки та суспільний запит на ії активну участь у життєдіяльності українського суспільства $є$ досить високими. І це при тому, що за всі роки незалежності державна влада слабо сприяла посиленню їі суспільно-економічної значущості. Так, за даними моніторингу соціальних змін в українському суспільстві, який проводиться Інститутом соціології НАН України, на запитання щодо рівня довіри до вчених України (2016 р.) $[13,494] 47,3 \%$ респондентів відповіли, що довіряють їм, (41,3\% переважно довіряють, 6,0\% цілком довіряють), 15,5\% - не довіряють, $37,1 \%$ - однозначно не визначились 3 цього питання. Стосовно можливості розвитку української держави та економіки без розвитку вітчизняної науки 62,7\% респондентів відзначили, що це неможливо, $7,8 \%$ - вказали, що такий варіант можливий, 29,4\% - не визначились 3 цього питання або пропонували свої варіанти відповідей. До можливості наукової кар'єри родичів або близьких людей схвально ставляться 70,8\% респондентів, не схвалюють такий вибір 6,5\% респондентів, 22,6\% не змогли дати відповідь на це запитання [14, 140].

На питання щодо того, на які рекомендації має спиратися влада при розробленні програм розвитку України відповіді респондентів розподілилися так: вітчизняних вчених - 35,4\%; закордонних експертів - 24,2\%; представників бізнесу та керівників підприємств - 24,1\%; 
політиків та державних діячів України - 20,3\%; громадських організацій країни - 19,1\%; вказали інші соціальні групи та не змогли визначитись 3 цього питання 27,9\%.

Однак незважаючи на високу довіру до науки, оцінки ії ефективності в українському суспільстві є достатньо критичними. Так, рівень вітчизняної науки порівняно зі світовим 67,9\% респондентів оцінили як такий, що відстає від світового рівня (42,4\% - вважають, що відстає суттєво, 25,5\% - що відстає певною мірою); 7,8\% вважають, що він загалом відповідає світовому рівню, 4,3\% - що відповідає світовому рівню, а за деякими позиціями навіть випереджає його, 18,5\% не визначились 3 цього питання. Що стосується ролі вітчизняної науки загалом та її окремих галузей у розвитку й оновленні українського суспільства, то 38,5\% респондентів вважають іiі незначною, 28,2\% - посередньою, 19,3\% - значною, 13,5\% не визначились 3 цього питання.

Для українського суспільства притаманними $є$ високі довіра до науки та суспільний запит на її активну участь в його життєдіяльності: більше половини населення цікавиться новинами науки i техніки; переважними джерелами інформації про досягнення науки і техніки є телебачення та Інтернет, які за сучасних умов мають найкращі можливості впливу на громадську думку.

Підкреслимо, що означене вище лише посилює парадоксальність ситуації, що склалася в Україні в тріаді взаємовідносин «держава наука - суспільство» навколо проблеми науково-технологічного та інноваційного розвитку національної економіки. По-перше, за весь період сучасної доби українська держава так і не змогла визначитись, що робити з наукою, яка дісталась їй у спадок в результаті напруженої роботи минулих поколінь вчених. «За всі роки незалежності України вітчизняна наука фінансувалася за залишковим принципом і не розглядалася як один із державних пріоритетів», - вважає президент НАН України Б.С. Патон [15]. По-друге, невизначеність, а радше негативне ставлення держави до науки сучасної української влади зумовлює ситуацію, коли вона не може ефективно бути включена в діалог із суспільством, в результаті чого слабо реалізується іiі суспільна функція, а це, своєю чергою, призводить до посилення відриву науки від суспільних потреб та інтересів. По-третє, всупереч державній невизначеності стосовно ролі науки, недостатності комунікацій «наука - суспільство», для українського суспільства, все ж $є$ характерними і висока довіра до науки, і суспільний запит на неї. 
Звідси випливає, що першочерговою причиною невдач України в інноваційному розвитку економіки $є$ неефективність влади, низька компетентність та незадовільний рівень спрямованості органів державної влади на реалізацію національної інноваційної політики. Виходить, допоки рівень глобальної спроможності національної державності в українському суспільстві суттєво перевищуватиме рівень конкурентної цілеспрямованості органів державної влади, доти українська економіка не матиме пріоритету інноваційного розвитку й надалі залишатиметься інноваційно-периферійною, а відтак створюватиме суттєві геостратегічні ризики щодо інтеграції України в європейський науково-інноваційний простір.

Нинішні українські реалії свідчать, що державна політика щодо науково-технологічної та інноваційної сфери й надалі $€$ мало зрозумілою.

Отже, аналіз особливостей розвитку науково-інноваційної сфери модернізації української економіки через призму сучасних напрямів НТІ політики країн Організації економічного співробітництва та розвитку (ОЕСР) доводить, що вітчизняна науково-технологічна та інноваційна політика, всупереч світовим тенденціям, слабо сприяє нарощуванню соціального потенціалу інноваційного розвитку національного господарського комплексу, зменшенню його інноваційної периферійності.

В українському суспільстві склалася парадоксальна ситуація: всупереч низьким оцінкам компетентності та зацікавленості органів державної влади в ефективному інноваційному розвитку національної економіки, низьким оцінкам ефективності науки та низькою поінформованістю громадської думки про науково-технічні та технологічні досягнення, характерним є як досить висока суспільна довіра до науки, так і соціальний запит на неї. Цей парадокс означає, що суспільна функція науки в українському соціально-економічному середовищі реалізується вкрай непродуктивно, що призводить до подальшого посилення відриву науки від суспільства. Звідси випливає, що як соціально-політичні, так і економічні умови сучасного українського суспільства не сприяють зростанню соціального потенціалу економічного розвитку, внаслідок чого інноваційна периферійність національного господарського комплексу матиме тенденцію лише до зростання. Слід відзначити також і те, що державна влада, незважаючи на постійні декларації про інноваційний розвиток національної економіки впродовж усього періоду незалежності України, так і не спромоглася створити необхідну для цього 
ефективну систему державного управління.

Об’єктивно нинішній стан соціального потенціалу науки визначає наш завтрашній час, можливість посісти гідне місце в європейській цивілізаційній спільноті та світі загалом. Суб'єктивно, в масовій свідомості зберігається високий рівень довіри, зокрема, до вітчизняних науковців і розуміння суттєвої ролі соціальної науки в суспільстві. Водночас перманентним постає соціальний запит на сучасну наукову і владну еліту, які здатні виправдовувати кредит довіри соціуму, формулювати цілі системної трансформації, визначати напрями подальшої модернізації суспільства на позиціях прагматичного вирішення проблеми його життєдіяльності та раціонально оптимістичної інтеграції до глобального людства.

Одним з основних напрямів державної політики сприяння модернізації економіки в Україні повинно стати як створення конкурентоспроможного на глобальному рівні соціально-економічного середовища, так і активне функціонування національної інноваційної системи (НIC). У нашій країні, що знаходиться тривалий час у перехідному періоді системної трансформації, неодмінними є створення у складі НІС спеціальних структур, спрямованих на прискорений розвиток соціального капіталу, а саме: забезпечення аудиту гуманітарних чинників; організація інноваційної системи відбору і підготовки кадрів; формування потоків інтелектуального капіталу; розгортання необхідних для цього досліджень та соціальних експериментів.

Стратегія подальшого існування й розвитку України може бути розроблена в контексті інноваційного типу сценарію. Модернізація тут розглядається як квінтесенція сучасного договору між державою і суспільством. Ініціюючи модернізацію, держава змушена обмежувати власну монополію на владу; співробітництво з соціально-інноваційними структурами на принципах довіри й взаємності сприятиме реформі системи державного управління. А одним з головних завдань цієї системи є зменшення/нейтралізація «агентів контрмодернізації» в державному управлінському апараті, бізнес-елітах та підприємницькому середовищі. 


\section{ЛIТЕРАТУРА}

1. Abramovitz M. Two Centuries of American Macroeconomic Growth. From Exploitation of Resource Abundance to Knowledge-Driven Development [Electronic Resource] / M. Abramovitz, P.David. - Access mode: http://www.merit.unu.edu/publications/rmpdf/1994/rm1994-027.pdf

2. Социальный потенциал инновационного развития экономики: украинские реалии. - К. : Институт социологии НАН Украины, 2014. - 353 с.

3. Головаха $C$. Модернізація й зміна системи цінностей в українському суспільстві / С.Головаха // Економіка і прогнозування. - 2013. - № 1. C. $125-142$.

4. Социальный потенциал инновационного развития экономики: украинские реалии. - К. : ИС НАН Украины, 2014. - 353 с.

5. Abramovitz M. Convergence and Deferred Catch-up. Productivity Leadership and Waning of American Exceptionalism [Electronic Resource] / M.Abramovitz, P.David. - Access mode: http://www.siepr.stanford.edu/papers/pdf/01-05.pdf

6. Martinelli A. Global Modernization:Rethinking the project of modernity / A.Martinelli. London: SAGE Publications, 2005. - 159 p.

7. Савельєв Ю. Соціокультурні виміри модернізації та економічний розвиток європейських суспільств: Україна в координатах цінностей та ідентичності / Ю.Савельєв. - Соціологія: теорія, методи, маркетинг.2016. - №3. - С. 18-37.

8. Фукуяма Ф. Доверие: социальные добродетели на пути к процветанию / Ф. Фукуяма.-М.:ООО «Издательство АСТ»:ЗАО НПП «Ермак», 2004. - 730 с.

9. Стан та законодавче забезпечення фінансування наукової та науковотехнічної діяльності: матеріали слухань у Комітеті Верховної Ради України 3 питань науки і освіти 13 березня 2013 року. - К., 2013. - 515 с. [Електронний ресурс]. - Режим доступу:

http://kno.rada.gov.ua/komosviti/control/uk/doccatalog/list?currDir=s2017

10. Global Competitiveness Report 2014-15 [Електронний ресурс]. - Режим доступу: http://www3.weforum.org/.

11. Розроблено за Global Competitiveness Report 2009-15 [Електронний peсурс]. - Режим доступу: http://www3.weforum.org/.

12. Петрушина T. Соціальний потенціал інноваційного розвитку економіки України / T.Петрушина // Соціологія: теорія, методи, маркетинг. 2014. - №4. - С. 66-93.

13. Українське суспільство: моніторинг соціальних змін. Вип. 3(17). К. : ІС НАН України, 2016. - 546 с.

14. Українське суспільство: моніторинг соціальних змін. Вип. 1(15). Том 2.К. : ІС НАН України, 2014. - 410 с. 
15. Патон Б.С. Недофінансування НАН України призведе до згортання дослідницьких проектів і втрати наукових кадрів / Б.С. Патон // Голос України. - 2016. - 22 січня. - С.4.

Чепурко Г.І., Головатюк В.М., Піддубний І.Д. Соціальний потенціал модернізації украӥнської економіки в контексті євроінтеграції.

У статті акцентується увага на значенні соціального потенціалу для модернізації української економіки за сучасних умов глобалізації. Відзначено, що інтеграція до європейської цивілізації є масштабним завданням країни для суттєвого підвищення іiі конкурентоспроможності на світовій арені. Соціальний потенціал має ключове значення для розвитку наукових знань, відкритості індивідів до інновацій у практичній реалізації спрямування модернізаційних процесів в економіці країни. Запропонована низка основних складових соціального потенціалу модернізації: соціальний капітал, соціальне-економічне середовище, державна влада, науковий ресурс. Ефективне використання цих компонентів в їх синергетичній взаємодії сприяе інноваційному розвитку української економіки.

Ключові слова: модернізація, соціальний потенціал, українська економіка, науковий ресурс, євроінтеграція, соціально-економічне середовище.

Чепурко Г.И., Головатюк В.М., Поддубный И.Д. Социальный потенцииал модернизаџии украинской экономики в контексте евроинтегращии.

В статье акцентируется внимание на значении социального потенциала для модернизации украинской экономики в современных условиях глобализации. Отмечено, что интеграция в европейскую цивилизацию является масштабным заданием страны для существенного повышения ее конкурентоспособности на мировой арене. Социальный потенциал имеет ключевое значение для развития научных знаний, открытости индивидов к инновациям в практической реализации направленности модернизационных процессов в экономике страны. Предложен ряд основных составляющих социального потенциала модернизации: социальный капитал, социальноэкономическая среда, государственная власть, научный ресурс. Эффективное использование этих компонентов в их синергетическом взаимодействии способствует инновационному развитию украинской экономики.

Ключевые слова: модернизация, социальный потенциал, украинская экономика, научный ресурс, евроинтеграция, социально-экономическая среда. 
Chepurko G., Golovatyuk V., Poddubny I. Social potential of modernization of Ukrainian economy in the context of European integration.

The article focuses at the importance of social potential for the modernization of the Ukrainian economy in the current conditions of globalization. It is noted that integration into European civilization is a large-scale task of the country for a significant increase of its competitiveness in the world. Social potential is of key importance for the development of scientific knowledge, the openness of individuals to innovations in the practical implementation of the orientation on modernization processes in the country's economy. A number of basic components of the social modernization potential are proposed: social capital, socio-economic environment, state power, scientific resource. The effective use of these components in their synergetic interaction contributes to the innovative development of the Ukrainian economy.

Key words: modernization, social potential, Ukrainian economy, scientific resource, eurointegration, socio-economic environment. 